\title{
OPEN Green leaves and seeds alcoholic extract controls Sporobulus indicus germination in laboratory conditions
}

\author{
Jean Flaviel de Sousa Macêdo ${ }^{1,5}$, Lylian Souto Ribeiro², Riselane de Lucena Alcântara Bruno², \\ Edna Ursulino Alves ${ }^{2}$, Alberício Pereira de Andrade ${ }^{2}$, Kilson Pinheiro Lopes ${ }^{3}$, \\ Franciscleudo Bezerra da Costa ${ }^{3}$, José Cola Zanuncio ${ }^{4}$ \& Wellington Souto Ribeiro ${ }^{3,5 *}$
}

High seed production makes Sporobolus indicus var. pyramidalis a difficult to control invasive grassland plant. The objective of the present study was to investigate the bioactivity of Cyperus rotundus, Phyllanthus tenellus and Ricinus communis green leaf extracts and of Carica papaya seeds on S. indicus germination without breaking dormancy, simulating the field conditions. The ethanolic extract bioactivity of $C$. rotundus, $P$. tenellus, $R$. communis green leaves and $C$. papaya seeds, at concentrations of 25,50 and $75 \%$ in $S$. indicus germination was evaluated. Carotenoids, flavonoids, soluble phenolic compounds and total tannins were quantified in the extracts. The chemical component concentrations varied between alcoholic extracts. The $P$. tenellus extracts at all dilutions and those of $R$. communis and C. papaya at $75 \%$ completely suppressed $S$. indicus seed germination at five and ten days which can be attributed to their high tannin concentration, total phenolic compounds and flavonoids.

The grass Sporobolus indicus var. pyramidalis Beauv ${ }^{1}$. is an invasive and aggressive nonnative weed, has become a serious threat in many perennial grass pastures distributed in all tropical regions reducing the quality and production of forage crops ${ }^{2}$.

The S. indicus var. pyramidalis percentage germination is low $(6.7-27 \%)^{2-4}$ due to the presence of a hard seed coat $^{3}$. However, the low germination is compensated by high seed production, making it difficult to control. A panicle $(30 \mathrm{~cm})$ of $S$. indicus var. pyramidalis has around one thousand seeds and one plant can produce more than 200 panicles per year ${ }^{5}$. S. indicus spp. produces more than 1,400 seed per panicle and nearly 45,000 seed per plant $^{3}$. Smutgrass seed are thought to remain viable for at least 2 years ${ }^{6}$.

In southern Florida, hexazinone, an expensive herbicide, is the only control option against this plant and it is applied in pastures when infestations of this grass reach $30 \%^{5,7,8}$. In Brazil, S. indicus var. pyramidalis is controlled with glyphosate $\left(360 \mathrm{~g} \mathrm{~L}^{-1}\right)$ or manually, in small areas when at low densities or in organic and agroecological production systems. In these systems, the plants are ripped, bagged and burned far from the pasture, but its seed reserve in the soil is large. Chemical products to control of $S$. indicus var. pyramidalis, are expensive or dangerous and its intensive use in integrated systems is a problem. This makes it necessary to develop strategies to manage this plant, including products based on plant extracts, mainly for organic and agroecological production ${ }^{9}$. In addition, modern agriculture seeks natural organic methods to reduce the extensive and intensive application of chemicals, that impact the environment, public health, and the cost of agricultural production ${ }^{10,11}$.

Allelochemicals, produced during secondary plant metabolism, may reduce the growth, survival and reproduction of invading species ${ }^{12,13}$. Phenolic compounds are allelochemicals deriveted the shikimic and acetic acid (polyketide) metabolic pathways in plants ${ }^{14}$. Cyperus rotundus L. (Cyperaceae), Phyllanthus tenellus Roxb.

${ }^{1}$ Departamento de Agroecologia e Agropecuária, Campus II, Universidade Estadual da Paraíba, Sítio Imbaúba s/no, 58117-000, Lagoa Seca, Paraíba, Brasil. 'Departamento de Fitotecnia de Ciências Ambientais, Campus II, Universidade Federal da Paraíba, 58397-000, Areia, Paraíba, Brasil. ${ }^{3}$ Programa de Pós-graduação em Horticultura Tropical, Universidade Federal de Campina Grande, 58.840-000, Pombal, Paraíba, Brasil. ${ }^{4}$ Departamento de Entomologia/BIOAGRO, Universidade Federal de Viçosa, 36570-900, Viçosa Minas Gerais, Brasil. ${ }^{5}$ These authors contributed equally: Jean Flaviel de Sousa Macêdo and Wellington Souto Ribeiro *email: wellingtisouto@yahoo. com.br 


\begin{tabular}{|l|l|l|l|l|l|}
\hline Species & C\% & TF & TT & SPC & TC \\
\hline \multirow{4}{*}{ Phyllanthus tenellus } & 25 & $0,32 \pm 0,03$ & $4,87 \pm 0,34$ & $0,89 \pm 0,09$ & - \\
\cline { 2 - 6 } & 50 & $0,97 \pm 0,03$ & $7,32 \pm 0,56$ & $1,25 \pm 0,11$ & - \\
\cline { 2 - 6 } & 75 & $1,47 \pm 0,02$ & $16,32 \pm 0,58$ & $3,01 \pm 0,13$ & - \\
\hline \multirow{4}{*}{ Cyperus rotundus } & 25 & $4,76 \pm 0,40$ & $4,08 \pm 0,20$ & $79,65 \pm 5,34$ & - \\
\cline { 2 - 6 } & 50 & $6,98 \pm 0,67$ & $6,97 \pm 0,30$ & $86,89 \pm 4,98$ & - \\
\cline { 2 - 6 } & 75 & $10,00 \pm 0,73$ & $8,13 \pm 0,61$ & $187,17 \pm 12,78$ & - \\
\hline \multirow{4}{*}{ Ricinus communis } & 25 & $0,42 \pm 0,02$ & $0,24 \pm 0,03$ & $215,87 \pm 32,87$ & $2,50 \pm 0,13$ \\
\cline { 2 - 6 } & 50 & $0,99 \pm 0,03$ & $0,31 \pm 0,10$ & $327,77 \pm 45,87$ & $3,98 \pm 0,43$ \\
\cline { 2 - 6 } & 75 & $1,76 \pm 0,02$ & $0,47 \pm 0,10$ & $754,23 \pm 54,44$ & $7,00 \pm 1,02$ \\
\cline { 2 - 6 } & 50 & - & $2,13 \pm 0,10$ & $5,78 \pm 0,23$ & $0,09 \pm 0,03$ \\
\cline { 2 - 6 } & 75 & - & $4,56 \pm 0,10$ & $11,76 \pm 0,90$ & $0,13 \pm 0,01$ \\
\hline
\end{tabular}

Table 1. Total flavonoids ( $m g 100 \mathrm{~g}^{-1}$ ) (TF), total tannins ( $\mathrm{mg}$ of catechin $\mathrm{g}^{-1}$ ) (TT), soluble phenolic compounds $\left(\mathrm{mg} \mathrm{kg}^{-1}\right)$ (SPC) and total carotenoids (TC) in alcoholic plant extracts with 25, 50 and $75 \%$ dilution. Extracts concentration $(\mathrm{C} \%)$.

(Phyllanthaceae), Ricinus communis L. (Euphorbiaceae) and Carica papaya L. (Caricaceae) seeds have toxicological properties. Gallic acid, chlorogenic acid, 3,4-dihydroxybenzaldehyde, p-hydroxybenzoic acid, catechol, tannic acid, ricinine are some of the allelochemical phenolic compounds found in these species ${ }^{15}$. But the allelopathic potential of these plants on seeds weeds needs to be better studied ${ }^{10}$. Aqueous extracts have been studied ${ }^{16-18}$, but many non-polar bioactive substances cannot be dissolved by water at room temperature, unlike organic solvents ${ }^{13}$. Polar solvents such as methanol, ethanol, acetone, or acetonitrile give much high extraction efficiencies ${ }^{14}$.

Phenolic compounds, originated to protect plants from oxidative damage, are also involved in plant allelopathy inducing changes in membrane permeability, inhibition of nutrient uptake, cell division, stretching and submicroscopic structure, altering enzyme activity, respiration, and synthesis of hormones and proteins ${ }^{14}$. Studies on the performance of phenolic compounds such as allelopaths can provide data to development sustainable methods of agriculture, forestry, natural resources and conservation of the environment.

The objective of the present study was to evaluate the bioactivity of alcoholic extracts of C. rotundus, P. tenellus, $R$. communis green leaves and C. papaya seeds with on the $S$. indicus var. pyramidalis germination without breaking dormancy, simulating the field conditions.

\section{Results}

The concentration of the chemical components varied between and among the alcohol extracts of $C$. rotundus, $P$. tenellus and $R$. communis green leaves and that of C. papaya seeds. Total flavonoids ranged from 0.32 ( $P$. tenellus

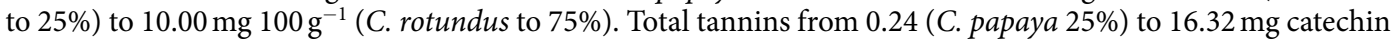
$\mathrm{g}^{-1}$ (P. tenellus $\left.75 \%\right)$. Soluble phenolic compounds from 0.89 (25\% P. tenellus) to $754.23 \mathrm{mg} \mathrm{kg}^{-1}$ (C. papaya $\left.75 \%\right)$.

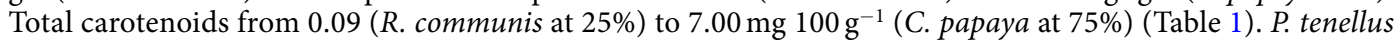
extracts at all dilutions and those of $R$. communis at $75 \%$ and C. papaya extracts completely suppressed $S$. indicus seed germination up to 30 days after aplication (Table 2).

\section{Discussion}

The variation in the concentration of chemical components between the alcoholic extracts confirms their wide occurrence and diversity in plants ${ }^{19,20}$ as reported for Artemisia campestres L. (Asteraceae), A. Herba halba L. (Asteraceae), A. arboresens L. (Asteraceae), A. arvensis L. (Asteraceae), Juniperus oxycedrus L. (Cupressaceae), Globularia alypum L. (Globulariaceae), Oudneya africana R. Br. (Brassicaceae), Monuta Route L. (Rutaceae), Thapsia garganica L. (Apiaceae), Thymelaea hirsuta L. (Thymelaeaceae) and Teucrium polium L. (Lamiaceae) ${ }^{21}$ and thirty-two other herbs ${ }^{22}$. This makes plants from different habitats in Sardinia, Italy ${ }^{23}$ of the same species growing in different conditions ${ }^{24}$ have chemical composition variation as reported for Myrtus communis $\mathrm{L}$. (Myrtaceae). The variation in the concentration of the chemical components between the alcoholic extracts is due to their proportions in the solvent/solute (dilution) which determines the effectiveness of the plant extracts and the isolated compounds $s^{25}$. In addition to dilution, the solvent may also alter the chemical composition of the extracts, as reported for Origanum vulgare L. (Lamiaceae ${ }^{26}$, Anthocleista grandiflora Gilg. (Gentianaceae) and Combretum erythrophyllum Burch. (Combretaceae) in wich compound quantity and diversity varied according to the extractors and their concentration ${ }^{25}$.

Flavonoids, a group of phenolic compounds resulting from secondary metabolism, are widely found in plants ${ }^{27}$ and their higher amount in the $75 \%$ C. rotundus extract agrees with that reported for the rhizome extract of this plant ${ }^{28-31}$. However, abiotic and biotic stress ${ }^{26}$ and changes in seasonal dynamics can affect compound content and when it is higher in the plant it will also be in the extract, as reported for Dryopteris erythrosora (DC Eaton) Kuntze (Dryopteridaceae) with the transport of flavonoids from the leaves to the stem in the growing season, comprising summer $\left(26.9^{\circ} \mathrm{C}\right)$ and early autumn $\left(16.9^{\circ} \mathrm{C}\right)$ in Shanghai, China ${ }^{32}$. The highest total tannin levels (another phenolic compound group) from the $P$. tenellus extract could be a response to the stressful environment in which this invasive species was collected ${ }^{33}$, area with stones, few soil and water deficit, in the microregion of Campina Grande, Paraíba, Brazil, with few soil and water deficits. The tannin accumulation, in this case, has an antioxidative function ${ }^{34}$ and agrees with the phytochemical profile of the methanolic solution 


\begin{tabular}{|c|c|c|c|c|c|c|c|}
\hline \multirow[b]{2}{*}{ Species } & \multirow[b]{2}{*}{$\mathrm{C} \%$} & \multicolumn{6}{|c|}{ Germination (\%) } \\
\hline & & 5th day & 10th day & 15th day & 20th day & 25th day & 30th day \\
\hline \multirow{4}{*}{ Phyllanthus tenellus } & 0 & $0 \pm 0.0 \mathrm{a}$ & $21 \pm 1.4 \mathrm{a}$ & $20 \pm 0.9 a$ & $20 \pm 1.6 a$ & $19 \pm 0.7 \mathrm{a}$ & $21 \pm 1.1 \mathrm{a}$ \\
\hline & 25 & $0 \pm 0.0 \mathrm{a}$ & $0 \pm 0.0 \mathrm{~b}$ & $0 \pm 0.0 \mathrm{~b}$ & $0 \pm 0.0 \mathrm{~b}$ & $0 \pm 0.0 \mathrm{~b}$ & $0 \pm 0.0 \mathrm{~b}$ \\
\hline & 50 & $0 \pm 0.0 \mathrm{a}$ & $0 \pm 0.0 \mathrm{~b}$ & $0 \pm 0.0 \mathrm{~b}$ & $0 \pm 0.0 \mathrm{~b}$ & $0 \pm 0.0 \mathrm{~b}$ & $0 \pm 0.0 \mathrm{~b}$ \\
\hline & 75 & $0 \pm 0.0 \mathrm{a}$ & $0 \pm 0.0 \mathrm{~b}$ & $0 \pm 0.0 \mathrm{~b}$ & $0 \pm 0.0 \mathrm{~b}$ & $0 \pm 0.0 \mathrm{~b}$ & $0 \pm 0.0 \mathrm{~b}$ \\
\hline \multirow{4}{*}{ Cyperus rotundus } & 0 & $0 \pm 0.0 \mathrm{a}$ & $19 \pm 1.9 \mathrm{a}$ & $19 \pm 1.5 \mathrm{a}$ & $18 \pm 0.7 \mathrm{a}$ & $17 \pm 1.1 \mathrm{a}$ & $18 \pm 0.9 \mathrm{a}$ \\
\hline & 25 & $0 \pm 0.0 \mathrm{a}$ & $14 \pm 2.4 \mathrm{~b}$ & $14 \pm 2.5 b$ & $15 \pm 2.0 \mathrm{~b}$ & $14 \pm 1.0 \mathrm{~b}$ & $14 \pm 1.8 \mathrm{~b}$ \\
\hline & 50 & $0 \pm 0.0 \mathrm{a}$ & $14 \pm 3.0 \mathrm{~b}$ & $15 \pm 2.1 b$ & $15 \pm 1.5 \mathrm{~b}$ & $13 \pm 2.0 \mathrm{~b}$ & $15 \pm 1.5 \mathrm{~b}$ \\
\hline & 75 & $0 \pm 0.0 \mathrm{a}$ & $1 \pm 0.4 \mathrm{c}$ & $1 \pm 2.6 c$ & $1 \pm 2.5 \mathrm{c}$ & $1 \pm 2.0 \mathrm{c}$ & $1 \pm 1.5 \mathrm{c}$ \\
\hline \multirow{4}{*}{ Ricinus communis } & 0 & $0 \pm 0.0 \mathrm{a}$ & $20 \pm 0.7 \mathrm{a}$ & $21 \pm 1.2 \mathrm{a}$ & $21 \pm 0.9 \mathrm{a}$ & $23 \pm 1.6 \mathrm{a}$ & $21 \pm 0.9 \mathrm{a}$ \\
\hline & 25 & $0 \pm 0.0 \mathrm{a}$ & $23 \pm 0.3 \mathrm{a}$ & $20 \pm 1.5 \mathrm{a}$ & $21 \pm 0.9 \mathrm{a}$ & $20 \pm 1.7 \mathrm{a}$ & $21 \pm 1.1 \mathrm{a}$ \\
\hline & 50 & $0 \pm 0.0 \mathrm{a}$ & $7 \pm 0.9 \mathrm{~b}$ & $6 \pm 1.3 \mathrm{~b}$ & $7 \pm 0.9 \mathrm{~b}$ & $5 \pm 0.9 \mathrm{~b}$ & $7 \pm 1.0 \mathrm{~b}$ \\
\hline & 75 & $0 \pm 0.0 \mathrm{a}$ & $0 \pm 0.0 \mathrm{c}$ & $0 \pm 0.0 \mathrm{c}$ & $0 \pm 0.0 \mathrm{c}$ & $0 \pm 0.0 \mathrm{c}$ & $0 \pm 0.0 \mathrm{c}$ \\
\hline \multirow{4}{*}{ Carica papaya } & 0 & $0 \pm 0.0 \mathrm{a}$ & $19 \pm 1.1 \mathrm{a}$ & $19 \pm 1.1 \mathrm{a}$ & $20 \pm 1.7 \mathrm{a}$ & $19 \pm 1.2 \mathrm{a}$ & $20 \pm 0.7 \mathrm{a}$ \\
\hline & 25 & $0 \pm 0.0 \mathrm{a}$ & $15 \pm 2.7 \mathrm{~b}$ & $15 \pm 1.4 \mathrm{~b}$ & $15 \pm 2.9 \mathrm{~b}$ & $15 \pm 1.7 \mathrm{~b}$ & $15 \pm 2.0 \mathrm{~b}$ \\
\hline & 50 & $0 \pm 0.0 \mathrm{a}$ & $12 \pm 1.3 \mathrm{~b}$ & $13 \pm 1.7 \mathrm{~b}$ & $14 \pm 3.3 \mathrm{~b}$ & $12 \pm 1.9 \mathrm{~b}$ & $15 \pm 2.7 \mathrm{~b}$ \\
\hline & 75 & $0 \pm 0.0 \mathrm{a}$ & $0 \pm 0.0 \mathrm{c}$ & $0 \pm 2.7 \mathrm{c}$ & $0 \pm 0.0 \mathrm{c}$ & $0 \pm 2.7 \mathrm{c}$ & $0 \pm 0.0 \mathrm{c}$ \\
\hline
\end{tabular}

Table 2. Germination percentage of Sporobolus indicus var. pyramidalis seeds treated with plant extracts. Extracts concentration (C\%). "Means followed by the same letter per column do not differ $(\mathrm{P}<0.05$ KruskallWallis test) by Mann-Whitney $U$-test.

(80\%) of the whole P. tenellus plant ${ }^{35}$. The highest phenolic compound content and total carotenoids in the $C$. papaya L. seed extract is due to its function in sanity and resistance to pests and diseases, as a strategy for seed survival ${ }^{36}$, mainly against oxidative stress ${ }^{37}$. These compunds act in response to environmental stress conditions protecting against injuries, as reported in the identification of the phenolic profile of papaya fruits ${ }^{36,38}$. Secondary products of metabolism such as flavonoids, tannins, phenolic compounds and carotenoids ${ }^{39}$, may act in inhibiting germination ${ }^{40}$ reducing tissue growth or causing death by increasing cell membrane permeability, as reported for Cucumis sativus L. (Cucurbitaceae) ${ }^{41}$, Lactuca sativa L. (Asteraceae) ${ }^{14}$, Phaseolus vulgaris L. (Fabaceae) ${ }^{42}$ resulting in the inhibition of radicular elongation and ultra structural changes and cell division.

The suppression of $S$. indicus germination by C. papaya, P. tenellus and R. communis extracts may be due to their high tannin concentration and total phenolic compounds (derived from the acetate and shikimic acid route or their combination $)^{39}$. These compounds bind strongly to proteins by hydrogen bonds and hydrophobic interaction, deactivating them and blocking germination metabolism $\mathrm{m}^{43,44}$ or preventing the access of free oxygen to the embryo and the release of carbon dioxide ${ }^{45}$. This was reported for Sorghum bicolor L. Moench. (Poaceae) which tannin content was correlated with its germination. The highest flavonoid concentration in C. rotundus, R. communis and C. papaya extracts at $75 \%$, also explains the allelopathic effect on S. indicus germination. In addition, the flavonoids are compounds with high antioxidant power ${ }^{46}$ suppressing germination by inhibiting the indole-acidase oxidase (IAA oxidase), gibberellic acid $\left(\mathrm{GA}_{3}\right)$ and indo-3-acetic acid (IAA) ${ }^{47}$. The allelopathic effect of Dittrichia viscosa (L.) W. Greuter extracts was attributed to flavonoids ${ }^{48}$ and, even at low concentrations (0.1-1.0\%), those of Ocimum gratissimum L. (Lamiaceae) inhibited the germination and growth of corn and beans $^{49}$. The suppressive germination effect by the C. papaya extract at $75 \%$ may also be due to caricacin ${ }^{50}$, which suppresses cell division and phytohormone production and increases the permeability of membranes, inhibiting germination $^{43,51}$. The absence of toxicity of the $R$. communis extract at 25 and $50 \%$ can be explained by their adsorption by allelopathic active compounds such as sugars and other $S$. indicus seed carbohydrates, whereas this was not sufficient at $75 \%$ concentration due to the high concentration. High sugar concentrations as well as of other carbohydrates, such as glucose and fructose, maltose, sucrose, raffinose, myo-inositol and galactinol have been reported for Poa annua L. ${ }^{52}$, Melinis minutiflora P. Beauv. (Poaceae), Echinolaena inflexa Poir. (Poaceae), and Lolium multiflorum L. (Poaceae) ${ }^{53}$ from the same $S$. indicus family. Ricin, a highly toxic R. communis heterodimeric protein is composed of polypeptide chains with an affinity for cell surface carbohydrates ${ }^{54-57}$ becomes inert when adsorbed by them thereby not influencing germination ${ }^{18,58,59}$. Lectin, a $\mathrm{N}$-acetylgalactosamine present in seeds, including those of the Poaceae family ${ }^{60}$ is another protein class with reversible carbohydrate binding capacity that can adsorb ricin and other allelopathic compounds, deactivating the $R$. communis extract atby inhibiting the germination of the invasive plant $S$. indicus var. pyramidalis.

\section{Conclusion}

Phyllanthus tenellus alcohol extracts at all R. communis concentrations and C. papaya, at 75\%, suppressed the germination of $S$. indicus var. pyramidalis. These extracts have the potential to manage this plant in organic and agroecological production systems. 


\begin{abstract}
Material and Methods
Raw material, preparation and characterization of extracts. Extracts were obtained from C. rotun$d u s$, . tenellus and R. communis green leaves and C. papaya seeds by immersion in $70 \%$ ethyl alcohol for seven days ${ }^{14}$. The alcohol was extracted at $250^{\circ} \mathrm{C}$ and the extract filtered and diluted in distilled water to obtain the concentrations of 25,50 and $75 \%$ and their effects were compared with distilled water (control). The chemical composition of extracts at all concentrations was characterized.
\end{abstract}

Soluble phenolic compounds. The extracts were prepared by adding $10 \mathrm{~mL}$ of methanol: acetic: water solution (50:3.7:46.3) to $10 \mathrm{mg}$ of extract, sonicated for $15 \mathrm{~min}$ and centrifuged (NT810 model, Nova Técnica Ind. Com. Equipamentos para Laboratório LTDA, Brazil) at $16,000 \mathrm{rpm} \mathrm{min}^{-1}$ for $15 \mathrm{~min}$. An aliquot of the extract $(0.2 \mathrm{~mL})$ was withdrawn and 1:10 (v/v) Folin-Ciocalte: water solution added. The final solution was incubated for $10 \mathrm{~min}$ at room temperature ${ }^{14}$. A total of $0.8 \mathrm{ml}$ of sodium carbonate $(7.5 \%)$ was added to the resulting solution, which was mixed and incubated for $30 \mathrm{~min}$ at room temperature. Soluble phenolic compound concentrations were determined using UV-Vis spectrophotometer (4001/4 model, Spectronic ${ }^{\circledR} 20$ GenesysTM, USA) at $473 \mathrm{~nm}$ with gallic acid as standard.

Total flavonoids. Flavonoids were extracted with ethyl alcohol solution $(95 \%)-\mathrm{HCl}(1.5 \mathrm{~N})$ at the ratio $85: 15^{15}$. An aliquot of $10 \mathrm{~mL}$ of the extract solution was added to $1.0 \mathrm{~g}$ of the alcoholic extract. The samples were vortexed for $2 \mathrm{~min}$ and the contents packed in amber flasks for $24 \mathrm{~h}$ at $4{ }^{\circ} \mathrm{C}$. After $24 \mathrm{~h}$, the material was centrifuged at 3,500 rpm $(2,380 \times g)$ for $10 \mathrm{~min}$ and the supernatant removed. The volume was completed to $10 \mathrm{ml}$ and readings were performed using a UV-Vis spectrophotometer (4001/4 model, Spectronic ${ }^{\circledR} 20$ GenesysTM, USA) at $374 \mathrm{~nm}$ with the results expressed in $\mathrm{mg} 100 \mathrm{~g}^{-1}$.

Total carotenoids. Total carotenoids were extracted in a steel vessel with an aliquot of $2.0 \mathrm{~g}$ of alcoholic extract, $6.0 \mathrm{~mL}$ of isopropyl alcohol and $2.0 \mathrm{~mL}$ of hexane stirred for $2 \mathrm{~min}^{61}$. The contents were transferred to an amber $125 \mathrm{~mL}$ separatory funnel, making up the volume with water. After $30 \mathrm{~min}$ resting, the material was washed, repeating the operation three times. The contents were filtered with powdered cotton wool with anhydrous sodium sulfate into a $10 \mathrm{~mL}$ volumetric flask wrapped with aluminum with $2.0 \mathrm{~mL}$ of acetone and the volume made up with hexane. The readings were performed in a UV-Vis spectrophotometer at $450 \mathrm{~nm}$ and the results expressed in $\mathrm{mg} 100 \mathrm{~g}^{-1}$.

Total tannins. The samples of alcoholic extracts were allowed to stand for $1 \mathrm{~h}$ in $40 \mathrm{~mL}$ of $50 \%$ methyl alcohol, centrifuged at $15,000 \mathrm{rpm}$ for $15 \mathrm{~min}$ and the supernatant transferred to a $100 \mathrm{~mL}$ volumetric flask. A $70 \%$ acetone solution was added to the precipitate, which was kept standing for a further $1 \mathrm{~h}$. The mixture was again centrifuged at $15,000 \mathrm{rpm}$ for $15 \mathrm{~min}$ and the supernatant discarded. The precipitate was placed in a thermostatic bath at $100^{\circ} \mathrm{C}$ for $3 \mathrm{~h}$, cooled in an ice bath, filtered into a $50 \mathrm{ml}$ volumetric flask and the volume filled with the extractive solution. The readings were made in $6 \mathrm{~mL}$ aliquots of butanol: $\mathrm{HCl}$ and $0.2 \mathrm{~mL}$ of $2 \mathrm{~N}: \mathrm{FeNH}_{4}\left(\mathrm{SO}_{4}\right) \cdot 12 \mathrm{H}_{2} \mathrm{O}$ per test tube. After stirring, these tubes were placed in a thermostatic bath at $100^{\circ} \mathrm{C}$ for $50 \mathrm{~min}$ and cooled in an ice bath. The reading was performed in a UV-Vis spectrophotometer at $550 \mathrm{~nm}$ and the results expressed in $\mathrm{mg}$ of catechin $\mathrm{g}^{-1}$.

Panicles collection. Panicles without evidence of herbivory and fungi and with mature seeds were collected from plants distributed in ten (10) farms with pastures infested by $S$. indicus var. pyramidalis in the state of Paraíba, northeastern Brazil. Mature seeds were randomly selected and naturally dried. The viability test was performed in duplicate in batches of 100 seeds of each property. The viability test was performed for 30 days ${ }^{62}$. However, seeds that did not germinate within 10 days were rotting ${ }^{4}$.

Bioassay. S. indicus germination was evaluated in triplicate with 100 seeds every 10 days in a germination box $\left(\right.$ Gerbox $\left.^{\circledR}\right)(11 \times 11 \times 3.5 \mathrm{~cm})$ with two germination paper $\left(G e r m i t e s t^{\circledR}\right)$ moistened with 18 ml of the different extracts and distilled water in the control. Seed dormancy were not broken to simulate field conditions. The germination assays were done in a germination chamber at $20^{\circ} \mathrm{C}$ with $14 \mathrm{~h}$ light per daily. Germination was evaluated daily by 10 days $^{4}$. Seeds with radicle protrusion were considered germinated. The percentage of germination was obtained with the formula: $\% \mathrm{G}=(\mathrm{N} / \mathrm{A}) * 100$, where: $\mathrm{N}=$ total number of seeds germinated; $\mathrm{A}=$ total number of seeds placed to germinate ${ }^{63-67}$.

Experimental design and statistical analysis. The experimental design was completely randomized with three replicates of 100 seeds. The germination rates was compared across independent samples by using non-parametric Kruskal Wallis $\mathrm{H}$ test. Further, Mann Whitney $U$ test was used to compare the two germination rates.

Received: 19 March 2018; Accepted: 29 October 2019;

Published online: 31 January 2020

\title{
References
}

1. Powell, G., Tosh, C. R. \& Hardie, J. Host plant selection by aphids: behavioral, evolutionary, and applied perspectives. Annu. Rev. Entomol. 51, 309-330, https://doi.org/10.1146/annurev.ento.51.110104.151107 (2006).

2. Rana, N., Wilder, B., Sellers, B., Ferrell, J. \& MacDonald, G. Effects of environmental factors on seed germination and emergence of smutgrass (Sporobolus indicus) varieties. Weed Sci. 60, 558-563, https://doi.org/10.1614/WS-D-11-00208.1 (2012).

3. Currey, W.L.R., Parradoand, D. W J. Seed characteristics of smutgrass. Pages 53-54 in Proceedings of the 32nd Soil Crop Science Society of Florida. Gainesville, FL: Soil and Crop Science Society of Florida, (1973). 
4. Guido, A. C. \& Pillar, D. H. V. D. Exploring seed to seed effects for understanding invasive species success. Perspect. Ecol. Conser. 15, 234-238, https://doi.org/10.1016/j.pecon.2017.07.006 (2017).

5. Ferrell, J. A., Mullahey, J. J., Dusky, J. A. \& Roka, F. M. Competition of giant smutgrass (Sporobolus indicus) in a bahiagrass pasture. WSSA. 54, 100-105, https://doi.org/10.1614/WS-05-061R1.1 (2006).

6. McCaleband, J. E. E. \& Hodges, M. Smutgrass control at Range Cattle Station, Ona, Florida. Pages 182-186 in Proceedings of the 24th Southern Weed Science Society. Southern Weed Science Society (1971).

7. Quattrocchi, U. CRC world dictionary of grasses: common names, scientific names, eponyms, synonyms, and etymology. 2383p (Boca Raton: CRC Press, 2006).

8. Rana, N. et al. Impact of soil $\mathrm{pH}$ on bahiagrass competition with giant smutgrass (Sporobolus indicus var. pyramidalis) and small smutgrass (Sporobolus indicus var. indicus). WSSA. 61, 109-116, https://doi.org/10.1614/WS-D-12-00070.1 (2013).

9. Jabran, K., Mahajan, G., Sardana, V. \& Chauhan, B. S. Allelopathy for weed control in agricultural systems. J. Crop. Prot. 72, 56-75, https://doi.org/10.1016/j.cropro.2015.03.004 (2015).

10. Musa, D. D., Esson, A. E., Shuaibu, B. U. \& Adebola, M. I. Allelopathic effect of Senna obtusifolia on the germination and growth of cowpea and maize. Afr. J. Plant. Soil. Res. 5, 71-74 (2016).

11. Hidangmayum, A. \& Sharma, R. Effect of different concentration of commercial seaweed liquid extract of Ascophylum nodosum on germination of onion (Allium cepa L.). J. Pharmacogn. Phytochem. 6, 1488-1481 (2017).

12. Zheng, Y. L. et al. Integrating novel chemical weapons and evolutionarily increased competitive ability in success of a tropical invader. N. Phytol. 205, 1350-1359, https://doi.org/10.1111/nph.13135 (2015).

13. Cheng, F. \& Cheng, Z. Research progress on the use of plant allelopathy in agriculture and the physiological and ecological mechanisms of allelopathy. Front. Plant. Sci. 6, e01020, https://doi.org/10.3389/fpls.2015.01020 (2015).

14. Li, Z. H., Wang, Q., Ruan, X., Pan, C. D. \& Jiang, D. A. Phenolics and plant allelopathy. Molecules 15, 8933-8952, https://doi. org/10.3390/molecules15128933 (2010).

15. Singh, R. K. \& Geetanjali, G. Phytochemical and pharmacological investigations of Ricinus communis Linn. Alg. J. Nat. Prod. 3 , $120-129(2015)$

16. Li, Y. C., Guo, Q. S., Shen, H. J., Fang, H. L. \& Redai, Y. Z. X. Preliminary isolation and identification of allelopathic compounds from Jatropha curcas L. fruit shells. J. Trop. Subtrop. Bot. 21, 73-77 (2013).

17. Singh, R. Geetanjali. Phytochemical and Pharmacological Investigations of Ricinus communis Linn. Alg. J. Nat. Prod. 3, 120-129 (2015).

18. Marwat, S. K. et al. Ricinus communis: Ethnomedicinal uses and pharmacological activities. Pak. J. Pharm. Sci. 30, 1815-1827 (2017).

19. Hrazdina, G., Borzel, A. J. \& Robinson, W. B. Studies on the stability of the anthocyanidin-3,5- diglucosides. Am. J. Enol. Viticult. 21, 201-204 (1970).

20. Figueiredo, A. C., Barroso, J. G., Pedro, L. G. \& Scheffer, J. J. C. Factors affecting secondary metabolite production in plants, volatile components and essential oils. Flavour. Frag. J. 23, 213-226, https://doi.org/10.1002/ffj.1875 (2008).

21. Djeridane, A. et al. Antioxidant activity of some Algerian medicinal plants extracts containing phenolic compounds. Food Chem. 97, 654-660, https://doi.org/10.1016/j.foodchem.2005.04.028 (2006).

22. Wojdyło, A., Oszmiański, J. \& Czemerys, R. Antioxidant activity and phenolic compounds in 32 selected herbs. Food Chem. 105, 940-949, https://doi.org/10.1016/j.foodchem.2007.04.038 (2007).

23. Petretto, G. L. et al. Variability of chemical composition and antioxidant activity of essential oils between Myrtus communis var. Leucocarpa DC and var. Melanocarpa DC. Food Chem. istry 197, 124-131, https://doi.org/10.1016/j.foodchem.2015.10.056 (2016).

24. Sulimaa, P., Krauze-Baranowska, M. \& Przyborowskia, J. A. Variations in the chemical composition and content of salicylic glycosides in the bark of Salix purpurea from natural locations and their significance for breeding. Fitoterapia 118, 118-125, https:// doi.org/10.1016/j.fitote.2017.03.005 (2017).

25. Eloff, J. N. Which extractant should be used for the screening and isolation of antimicrobial components from plants? J. Ethnopharmacol. 60, 1-8, https://doi.org/10.1016/S0378-8741(97)00123-2 (1998).

26. Teixeira, B. et al. Chemical composition and bioactivity of different oregano (Origanum vulgare) extracts and essential oil. J. Sci. Food Agric. 30, 2707-2714, https://doi.org/10.1002/jsfa.6089 (2013).

27. Manoj, G. S. \& Murugan, K. Phenolic profiles, antimicrobial and antioxidant potentiality of methanolic extract of a liverwort, Plagiochila beddomei Steph. Indian. J. Nat. Prod. Resour. 3, 173-183 (2012).

28. Sunil, A. G. et al. Total oligomeric flavonoids of Cyperus rotundus ameliorates neurological deficits, excitotoxicity and behavioral alterations induced by cerebral ischemic-reperfusion injury in rats. Brain Res. Bull. 84, 394-405 (2014).

29. Kumar, K. H., Razack, S., Ilaiyaraja, N. \& Khanum, F. Phytochemical analysis and biological properties of Cyperus rotundus L. Ind. Crop. Prod. 52, 815-826, https://doi.org/10.1016/j.indcrop.2013.11.040 (2014).

30. Kumar, K. H., Tamatam, A., Pal, A. \& Khanum, F. Neuroprotective effects of Cyperus rotundus on SIN-1 induced nitric oxide generation and protein nitration: ameliorative effect against apoptosis mediated neuronal cell damage. Neurotoxicology 34, 150-159, https://doi.org/10.1016/j.neuro.2012.11.002 (2013).

31. Kandikattua, H. K. et al. LC-ESI-MS/MS analysis of total oligomeric flavonoid fraction of Cyperus rotundus and its antioxidant, macromolecule damage protective and antihemolytic effects. Pathophysiology 22, 165-173, https://doi.org/10.1016/j. pathophys.2015.07.001 (2015)

32. Xie, Y. et al. Seasonal dynamics of total flavonoid contents and antioxidant activity of Dryopteris erythrosora. Food Chem. 186, 113-118, https://doi.org/10.1016/j.foodchem.2014.05.024 (2015).

33. Silva, T. C. L. et al. Estudo da toxicidade subcrônica de Phyllanthus tenellus Roxb: avaliação comportamental. Rev. Enferm. 1, 17-22, https://doi.org/10.5205/0201200803 (2008).

34. Williams, R. J., Spencer, J. P. E. \& Rice, C. E. Flavonoids: Antioxidants or signaling molecules? Free. Radic. Biol. Med. 36, 838-849, https://doi.org/10.1016/j.freeradbiomed.2004.01.001 (2004).

35. Komuraiah, A. et al. Antibacterial studies and phytochemical constituents of South Indian Phyllanthus species. Afr. J. Biotechnol. 8, 4991-4995 (2009).

36. Imani, A., et al. Seed Sci Technol. 39, 204-207 (2011).

37. Tommasi, F., Paciolla, C., Pinto, M. C. \& Gara, L. A. Comparative study of glutathione and ascorbate metabolism during germination of Pinus pinea L. seeds. J. Exp. Bot. 52, 1647-1654 (2001).

38. Rivera-Pastrana, D. M., Yahia, E. M. \& González-Aguilar, G. A. Phenolic and carotenoid profiles of papaya fruit (Carica papaya L.) and their contents under low temperature storage. J. Sci. Food Agric. 90, 2358-2365, https://doi.org/10.1002/jsfa.4092 (2010).

39. Yang, S. et al. Chemical constituents of Cinnamomum septentrionale leaf litter and its allelopathic activity on the growth of maize (Zea mays). Nat. Prod. Res. 31, 1314-1317, https://doi.org/10.1080/14786419.2016.1236102 (2017).

40. Šežiene, V., Baležentiené, L. \& Maruška, A. Identification and allelochemical activity of phenolic compounds in extracts from the dominant plant species established in clear-cuts of Scots pine stands. iForest. 10, e1-e6, https://doi.org/10.3832/ifor 1791-009 (2017).

41. Li, H. H., Inoue, M., Nishimura, H., Mizutani, J. \& Tsuzuki, E. Interaction of trans-cinnamic acid, its related phenolic allelochemicals, and abscisic-acid in seedling growth and seed-germination of lettuce. J. Chem. Ecol. 19, 1775-1787, https://doi.org/10.1007/ BF00982307 (1993).

42. Cruz, O. R., Anaya, A. L. \& Hernandez-Bautista, B. E. Effects of allelochemical stress produced by sicyosdeppei on seedling root ultrastructure of Phaseolous valgaris and Cucubita ficifolia. J. Chem. Ecol. 24, 2039-2057 (1998).

43. Sartor, L. R., Chini, P. F. A. N., Martin, T. N., Marchese, J. A. \& Soares, A. B. Alelopatia de acículas de Pinus taeda na germinação e no desenvolvimento de plântulas de Avena strigosa. Ciênc. Rural. 39, 1653-1659, https://doi.org/10.1590/S0103-84782009000600004 (2009). 
44. Parr, A.J. \& Bolwell, G.P. Phenols in the plant and in man. The potential for possible nutritional enhancement of the diet by modifying the phenols content or profile. J. Agric Food Chem. 80, 985-1012. 10.1002/(SICI)1097-0010(20000515)80:7<985::AIDJSFA572>3.0.CO;2-7 (2000).

45. Weidner, S. et al. Analysis of phenolic compounds and antioxidant abilities of extracts from germinating Vitis californica seeds submitted to cold stress conditions and recovery after the stress. Int. J. Mol. Sci. 15, 16211-16225, https://doi.org/10.3390/ ijms150916211 (2014).

46. Dridi, A., Hadef, Y. \& Bouloudani, L. Determination of total phenol, flavonoid, antioxidant and antimicrobial activity of methanolic extract of Teucrium polium L. in Algerian East. J. Pharmacogn. Phytochem. Res. 8, 1566-1570 (2016).

47. Hinderer, W., Petersen, M. \& Seitz, H. U. Inhibition of flavonoid biosynthesis by gibberellic acid in cell suspension cultures of Daucus carota L. Planta 160, 544-549, https://doi.org/10.1007/BF00411143 (1984).

48. Grande, M., Piera, F., Cuenca, A., Torres, P. \& Bellido, I. Flavonoids from Inula viscosa. Planta Medica 51, 414-419, https://doi. org/10.1055/s-2007-969536 (1985).

49. Macdonald, I. O., Oludare, A. S. \& Olabiyi, A. Phytotoxic and anti-microbial activities of flavonoids in Ocimum gratissimum. Life Sci. 7, 45-48 (2010)

50. Reyes, M. N., Perez, A. \& Cuevas, J. Detecting endogenous growth regulators on the sarcotesta, sclerotesta, endosperm and embryo by paper chromatography on fresh and old seeds of two papaya varieties. J. Agr. U Puerto Rico 64, 164-172 (1980).

51. Karakaya, S. Bioavailability of phenolic compounds. Crit. Rev. Food Sci. Nutr. 44, 453-464 (2004).

52. Kellmann-Sopyła, W., Lahuta, L. B., Giełwanowska, I. \& Górecki, R. J. Soluble carbohydrates in developing and mature diaspores of polar Caryophyllaceae and Poaceae. Acta Physiol. Plant. 37, e118, https://doi.org/10.1007/s11738-015-1866-z (2015).

53. Souza, A., Sandrin, C. Z., Moraes, M. G. \& Ribeiro, R. C. L. F. Diurnal variations of non-structural carbohydrates in vegetative tissues of Melinis minutiflora, Echinolaena inflexa and Lolium multiflorum (Poaceae). Braz. J. Bot. 28, 755-763, https://doi.org/10.1590/ S0100-84042005000400010 (2005).

54. Deeks, E. D. et al. The low lysine content of ricin A chain reduces the risk of proteolytic degradation after translocation from the endoplasmic reticulum to the cytosol. Biochem. 41, 3405-3413 (2001).

55. Lord, M. J. et al. Ricin. Mechanism of cytotoxicity. Toxicol. Rev. 22, 53-64 (2003).

56. Barbieri, L. et al. Enzymatic activity of toxic and non-toxic type 2 ribosome-inactivating proteins. FEBS Lett. 563, e00286-8, https:// doi.org/10.1016/S0014-5793(04)00286-8 (2004).

57. Jasheway, K., Pruet, J., Anslyn, E. V. \& Robertus, J. D. Structure-based design of ricin inhibitors. Toxins 3, 1233-1248, https://doi. org/10.3390/toxins3101233 (2011).

58. Etzler, M. E. et al. A Nod factor binding lectin with apyrase activity from legume roots. Proc. Natl. Acad. Sci. USA 96, 5856-5861 (1999).

59. Kalsi, G. \& Etzler, M. E. Localization of a Nod factor-binding protein in legume roots and factors influencing its distribution and expression. Plant. Physiol. 124, 1039-1048, https://doi.org/10.1104/pp.124.3.1039 (2000).

60. Rüdiger, H. \& Gabius, H. J. Plant lectins: occurrence, biochemistry, functions and applications. Glycoconj. J. 18, 589-613 (2001)

61. Bhadoria, P. B. S. Allelopathy: a natural way towards weed management. Am. J. Agric. Exp. 1, 7-20 (2011).

62. Brasil. Ministério da Agricultura, Pecuária e Abastecimento. Regras para análise de sementes. 399p (Brasília: Mapa/ACS, 2009).

63. Betts. J. \& Officer, D. Control of giant parramatta grass: Agnote DPI/354, Orange: NSW Agriculture, 11 p. (2001).

64. Fu, M., Feng, H. J., Chen, Y., Wang, D. B. \& Yang., G. Z. Antioxidant activity of Garcinia xanthochymus leaf, root and fruit extracts in vitro. Chin. J. Nat. Medicines. 10, 129-134 (2012).

65. Francis, F. J. Analysis of anthocyanins. In: Markakis, P. Anthocyanins as food colors. (p.181-206). London: Academic Press (1982).

66. Higby, W. K. A simplified method for determination of some the carotenoid distribution in natural and carotene fortified orange juice. J. Food Sci. 27, 42-49, https://doi.org/10.1111/j.1365-2621.1962.tb00055.x (1962).

67. Dixon, R. A. \& Paiva, N. L. Stress-induced phenylpropanoid metabolism. Plant. Cell 7, 1085-1097, https://doi.org/10.1105/ tpc.7.7.1085 (1995).

\section{Acknowledgements}

To "Conselho Nacional de Desenvolvimento Científico e Tecnológico (CNPq), Coordenação de Aperfeiçoamento de Pessoal de Nível Superior (CAPES) and Fundação de Amparo à Pesquisa do Estado de Minas Gerais (FAPEMIG) for financial support.

\section{Author contributions}

W.S.R., R.L.A.B., E.U.A. and J.F.S.M. designed the research; J.F.S.M., L.S.R. and W.S.R. performed the experiments; W.S.R., J.C.Z., R.L.A.B., K.P.L., A.P.A., F.B.C. and J.F.S.M. wrote the manuscript. All authors approved the manuscript.

\section{Competing interests}

The authors declare no competing interests.

\section{Additional information}

Correspondence and requests for materials should be addressed to W.S.R.

Reprints and permissions information is available at www.nature.com/reprints.

Publisher's note Springer Nature remains neutral with regard to jurisdictional claims in published maps and institutional affiliations.

Open Access This article is licensed under a Creative Commons Attribution 4.0 International License, which permits use, sharing, adaptation, distribution and reproduction in any medium or format, as long as you give appropriate credit to the original author(s) and the source, provide a link to the Creative Commons license, and indicate if changes were made. The images or other third party material in this article are included in the article's Creative Commons license, unless indicated otherwise in a credit line to the material. If material is not included in the article's Creative Commons license and your intended use is not permitted by statutory regulation or exceeds the permitted use, you will need to obtain permission directly from the copyright holder. To view a copy of this license, visit http://creativecommons.org/licenses/by/4.0/.

(C) The Author(s) 2020 